Copyright (C) 2019 by Academic Publishing House Researcher

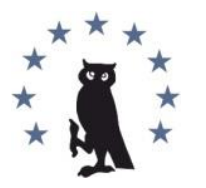

Published in the Russian Federation

European Researcher. Series A

Has been issued since 2010.

E-ISSN 2224-0136

2019, 10(3): 148-155

DOI: $10.13187 /$ er.2019.3.148

www.erjournal.ru

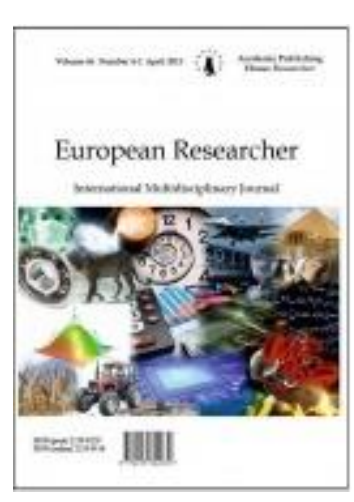

\title{
Land Acquisition and Involuntary Displacement: A Study of Changing State Society Relations
}

\author{
Sribas Goswami a * \\ ${ }^{a}$ Serampore College, Hooghly, West Bengal, India
}

\begin{abstract}
The present study is related to the problems of land acquisition for new industrial establishment, mining-induced displacement and resettlement occurring in different regions of West Bengal, India as a highly diverse regional socioeconomic issue. The study finds the source of challenges to public law and institutions providing humanitarian assistance as well as a matter of deep concern for human rights. This study also finds various dimensions of bulk land acquisition cases in Southern Bengal and problems associated with it. Thus, the land acquisition due to coal mining is increasingly becoming a coercive operation lacking in sensitivity to human consequences involved in trail if devastation and trauma it leaves behind. The piece of work probes into the deep of land acquisition policy of state government and people's reaction on land acquisition for establishment of new industry as well as extension of existing industry. The findings focus on various dimensions of bulk land acquisition cases in Southern Bengal and problems associated with it.
\end{abstract}

Keywords: coal mining, Displacement, Land acquisition, discrimination, environment.

\section{Introduction}

Displacement constitutes a major human problem in India. It dislocates People from their home, land \& environment and has traumatic consequences for their lives. Displacement can be caused by natural calamities such as flood, cyclone, tsunami, earthquake \& manmade factors such as political conflict, wars \& social strife. Development process, also man-made, has been added to the third source. While the first two causes have been a recurring phenomenon in the evolution of civilization, the third cause has emerged from the efforts of governments to modernize traditional societies. Of the three, the first two categories of displacement are unplanned \& usually unanticipated. The third category of displacement, however, is the result of prior \& conscious planning \& therefore anticipated. Of the two categories of unplanned displacement, the one that is due to natural calamities is usually of a shorter duration while the rather arising out of war, political conflict, \& social strife may have a little longer duration \&, in some situations, even of a permanent nature if the issues giving rise to it do not set satisfactorily resolved. But displacement from development projects is invariably permanent. This is because modern development is associated with big projects requiring huge areas of land, such as dams, airports, extraction of minerals, industrial plants, housing, provision of social service, etc. Since huge chunks of vacant land at a particular location on are available in rural areas only, though already under productive use by and large, it is the people in rural areas subsisting on these lands who bear the brunt of

\footnotetext{
${ }^{*}$ Corresponding author

E-mail addresses: sribasgoswami@gmail.com (S. Goswami)
} 
acquisition for them. As a result of this acquisition, the persons affected by $t$ are shifted to alternative location. The acquisition of land is carried out in a specified manner under a law which empowers the state to do so even without the consent of affected persons in public interest though a limited opportunity is given to them to raise any objection and the acquisition authority is required to compensate the land losers for this loss. Altogether, this exercise is heavily tilted in favour of the state which has overriding powers to take over the desired land, if necessary, by using force. Thus, the land acquisition is increasingly becoming a coercive operation lacking in sensitivity to human consequences involved in trail if devastation and trauma it leaves behind. There are several laws, central and state, under which land is acquired. While most other laws confine the acquisition for a specified sector of 'public purpose' such as coal mines, atomic energy, post and telegraph, highways, town planning, bulk of the acquisition takes place under the Land Acquisition Act, 1894 which applies to acquisition for any 'public purpose' and also provides the general structural framework for it (Goswami, 2019). The law was enacted by the colonial government along with the Indian Forest Act, 1865 to have control over natural resources of the country for their commercial exploitation. The acquisition law has continued to be used by the government after Independence for diverse development activities. This has led to the displacement of a large number of persons from their land, habitat and livelihood. The changes made in the Act in 1984 extended its use to acquisition of land for companies, public and private including registered societies and cooperatives, as well which added to the scope of acquisition. The shift to a neoliberal economy and its integration with the global economic order has widened the scale of acquisition of land and accelerated its pace. The enactment of Special Economic Zone (SEZ) Act, 2005 has brought a new dimension to the demand for acquisition of land in terms of area, location, size and geographical spread (Goswami, 2019). The resistance to such acquisition has been spontaneous and widespread the government has responded with use of force to suppress this opposition. Land acquisition is a burning problem in present time. The impacts of development projects occur in different forms. While significant benefits result for the society, the project area people may often bear the brunt of adverse impacts. This can happen, for example, when they are forced to relocate to make way for such interventions. There is now a growing concern over the fate of the displaced people. This has given rise to the need to understand the implications of adverse project impacts so that mitigation plans could be put in place in advance. The mining industry is frequently associated with decisions that have enormous social consequences. One of the most negative effects of mining today is the forcing of thousands of people to abandon their current places of residence. The acquisition of agricultural land for industrialization leads to a number of socio-economic consequences. These socio-political developments raised the level of consciousness and expectation about economic development among the poorer sections (landless labourers, marginal farmers, rural artisans etc.) of the rural population in India. Now it has been discussed in Economics, Sociology, Development studies, Law, Policy making, Political science, Geography etc. This problem may be studied from different perspectives to make feasible solution so that developmental activities will continue in future without compromising the social peace.

\section{Objectives of the Study:}

1. To study the socio-economic impact of the land acquisition on rural people. For this purpose we include those whose primary occupation is agricultural and non-agricultural work, in order to gauge the effect of the acquisition on these groups as well.

2. To examine the changes in employment status of the affected people in pre \& post acquisition scenario. land.

3. To focus on the types of compensation offered by the state government to the owners of

4. To see how the compensation is being used (where it is already done).

5. To assess the impact of displacement in living standard of the people involved.

7. To make recommendations on the basis of the findings of the study. Those recommendations are expected to be very helpful in Government's policy making.

\section{Methodology of the study}

The present study the area of the study is South Bengal which includes districts namely west Burdwan, Bankura and Purulia which have the highest concentration of several industries in West Bengal, India. Both descriptive and analytical approach is proposed for the study. As a tool an interview schedule is prepared to collect primary information from the people. Other distracts like 
Birbhum and Hooghly have been visited for study. The study mainly based on direct intensive observation and interviews with individuals affected by land acquisition. The demographic and economic surveys are conducted among all the households with the help of structured and openended questionnaire schedules. The qualitative information regarding the feeling and attitude of the acquisition of the affected persons are collected through repeated conversations with those persons over long period of time. The stories of hardship and economic crisis are addressed from individual family members by the case study method. Apart from the above mentioned field study, the earlier published and unpublished field materials collected from different sources are used in this study.

\section{Results and discussions}

The mining activities induces the growth should be a holistic notion that encompasses the progressive development in the quality of individual's life in terms of food, clothing and shelter and the environment for a healthy living with rising longevity of life and happiness. In West Bengal the development process reveals the indications and effects of widening inequalities between the "havese and "have-nots" and the growing deprivation of the vulnerable and marginalized sectors of the population (World Bank, 2007). There are very small trickle down effects of the economic development associated with this model of growth. But when it is necessary to undertake development projects that engage the displacement of communities, it is indispensable that these projects obtain the legal permission and support of the people who are affected and that in return for giving up their land and homes they receive priority if not exclusive rights to the benefits emanating from these projects (Goswami, 20018).

The study shows that respondent's age groups. Majority of the respondents fall under the age groups of 18-35 years and indicates the gender of the respondents with $15 \%$ of the respondents being male and $85 \%$ being female. Findings depicts that the major occupation of the respondents $70 \%$ are involved in agriculture and agricultural activities, $30 \%$ in other occupation namely as homemakers. Data shows 33 \% of the respondents earn less than Rs. 25,00o per annum, 40 \% earn more than Rs. 25,000 per annum and $26 \%$ don't have a calculable income as they are homemakers.

When the participants were asked if they make use of the proposed project land, most of them said that since this land belongs to the Ukhra, only some family members uses this land for seasonal cultivation. Since this land is used as a transit point for the people from Birbhum district most of the community members from Burdwan district use this route to travel to Birbhum to carry out their agricultural activities in Pandabeswar area.

The proposed land to be acquired is mainly used for seasonal cultivation because during rainy season the water level of the River Ajay rises up to this proposed acquired land. So the people cannot cultivate during the heavy monsoon season. However, most of the years this land remain unused and is used as a transit point by the community members (Goswami, 2018).

As per the findings more than 1000 hectares of land has been lost over a span of 20 years in only two blocks in Asansol subdivision and Burdwan district. The effect of land loss on agricultural activities may however be more objectively estimated through the statistics of number of persons employed in agriculture and their migration if any. The decrease of cultivable land is clearly visible in Raniganj coalfield is estimated $17.40 \%$.

\section{4a. Displacement as a Problem}

The problem of displacement is not merely economic; it is also a socio-cultural problem because it disturbs a network of social relationships supporting an ethos and a way of life. It affects the entire gamut of traditional activity and an established social order. It forces people to adopt new ways of occupational activities and an unknown environment. As such, the process is akin to 'replacement' in a new location. The displaced people are forced to change their social patterns, without getting any compensation for social costs and, thus, they are under pressure, causing a situation of socio-cultural stress (Corbridge, 2004).

\section{4.b Development versus Displacement}

Displacement claims the social and human costs of development that some citizens have to bear as best as they tend to promote the greater good of all. The evil (at least in the Benthamite sense as deliberative imposition of pain and suffering) is outweighed by the larger 'good (welfare) 
arising from 'development' projects. Costs are simply inevitable; there is no development without displacement. All that developmental planning should do, we are constantly told, is to engage in cost-benefit analysis, especially factoring in social and human costs of displacement, and provide for measures of rehabilitation and compensation. Most Indian developmental projects, insofar as they affect the impoverished masses, ignore both these aspects (Upadhyay, 2009).

There were several struggles against rules of land acquisition and the changes made in the colonial times, the best known among them being the one of Mulshi-Peta near Pune in the 1920s (Bhuskute, 1997). The struggle was appropriated by the freedom fighters. But, though they opposed the colonial government on this particular issue, the nationalist leaders had themselves internalized much of the colonial value system including that of the eminent domain. So, the thinking behind development in India remains more or less unchanged even half a century after independence (Lahiri-Dutt, 2012). When they became the decision-makers of independent India, the freedom fighters who had earlier supported the Mulshi-Peta struggle, continued to use the same colonial legislation to displace people in the name of national development. There has been much greater displacement and many more struggles after independence, because of the policies adopted for the use of land, water, forests and other resources. Displacement has caused impoverishment of the already poor downtrodden. There has been an enormous increase in the number of DPs and PAPs. Despite this, no official database exists on the total number and the type of DPs/PAPs. The country does not have a uniform rehabilitation policy though millions have been deprived of their lands and livelihoods (Morris, 2009).

\section{4.c Resettlement and Rehabilitation}

Resettlement of the displaced people is one-time relocation at a new site with payment of compensation for the land acquired and without other support such as jobs, training and welfare inputs to resettle in a new society and economic situation. Rehabilitation focuses on social and cultural factors and attempts to rebind the dispossessed livelihoods of the displaced and projectaffected people. It is not limited to economic compensation but, goes beyond to include welfare approach.

Rehabilitation is more often understood as an economic rather than a psycho-sociological phenomenon resulting from displacement. It is normally perceived as a 'planned change effort'. In a strict sense, it implies that, the overall objective of the change is to restore the situation to its original condition (Stuligross, 2008). The nature of rehabilitation is quite different from other developmental processes. All developmental efforts imply planned change to improve existing conditions, whereas rehabilitation is designed to restore the status quo. This makes it imperative to understand the term rehabilitation in a much wider perspective, and its components, which make it different from other developmental processes (Sharma, 2003). However, rehabilitation should go beyond maintaining of the status quo and adopt welfare approach to improve the standard of living of the displaced population

\section{4.d Components of Rehabilitation}

Displacement and rehabilitation of people are required when certain antecedent conditions of the displaced, the cognitive state of the individuals and their affective state. He further describes their manifest and rehabilitation programme which includes allotment of land, house, occupation and many other facilities required for resettlement and consideration of further demands by people from the government.

The process of rehabilitation has to be carried out along with resettlement and it should restore the socio-economic status of the displaced. Land for land is considered as one of the ways of rehabilitation of the displaced persons, whose economy centres on agriculture. There are also other ways of rehabilitation, which include engagement in small scale and cottage industries, dairy, piggery, fishery, poultry etc. PAPs have been demanding employment in the concerned project.

Cernea (1991) has identified eight main potential risks of impoverishment in case of the displaced persons. These are: (i) landlessness (ii) joblessness, (ii) homelessness, (iv) marginalization, (v) increased morbidity and mortality, (vi) food insecurity, (vii) loss of access to common property, and (viii) social disintegration. Resettlement and rehabilitation (R\&R) approach should focus on overcoming these risks. Social and cultural aspects should be wellconsidered in the process of rehabilitation.

\section{4.e Land-based rehabilitation is governed by}

1. Replacement of livelihood lost; 
2. The ownership of the replaced means of production;

3. 'Quality of life' after rehabilitation;

4. Security/guarantee against future displacement or multiple displacement; and.

5. 'Land for land' to be one of the main criteria for replacement of livelihood lost.

Income restoration is the basic objective of rehabilitation, the restoration activities should be based on the principle that no project-affected person shall be worse off than he shall or she was before the land acquisition. Restoration income is an important part of rehabilitating individuals, households, and socio-economic and cultural systems in affected communities.

To achieve this objective, preparation of income restoration (IR) programme could be approached as if they were economic development programme in their own right. Income restoration schemes could be designed in consultation with affected persons and they will explicitly approve programme designed to benefit them.

Income restoration entitlements are provided to the persons losing livelihood or suffering loss of income as a result of land acquisition in urban areas. These include land-based economic activities as well as non-land economic activities.

Individual income restoration schemes should consider the resource base of affected person and their socio-economic characteristics and preferences. These should consider their education level, skill possession and likely economic activities in the post-displacement period, extent of land left and extent of land purchased. Along with this, the suitability of economic activity to supplement the income and market potential and marketing facilities should be assessed.

Although it is widely recognized that the best option is to allow them to continue their former occupations, circumstances may not permit this option. When they elect to change activities, possible income restoration options could be explored. In addition, long-term socio-economic monitoring of the displaced is considered an important aspect of rehabilitation. It is evident that social support accompanied with sociological analysis helps in controlling social and cultural stress. The sociologists can play an important role in rehabilitation of the displaced.

\section{4.f Features of Displacement and Methodology}

Development has created a situation where more and more land is being acquired for urban development and lakhs of people are being displaced from their communities and traditional way of life. In the first part of the chapter, an attempt has been made to discuss the features of displacement, urban development and problems of displacement. In the second part, methodologies of resettlement and rehabilitation relevant to this study, areas of study and social background of sample population have been analyzed (Deininger et al., 2011).

\section{4.g Features of Displacement}

The fundamental feature of forced displacement is that it causes a profound unravelling of existing patterns of social organization. This unravelling occurs at many levels. When people are forcibly moved production systems are dismantled. Long established residential communities and settlements are disorganized, while kinship groups and family systems are often scattered (JhaThakur, 2008). Lives sustaining informal social networks that provide mutual help are rendered non-functional. Trade linkages between producers and their customer base are interrupted, and local labour markets are disrupted. Formal and informal associations, and self-organized services, are wiped out by the sudden scattering of their membership. Traditional management systems tend to lose their leaders. The coerced abandonment of symbolic markers, or of spatial contexts, cuts off some of the physical and psychological linkages with the past and saps at the roots of people's cultural identity. This indicates change in social and cultural aspects of the displaced persons (Szablowski, 2010).

\section{4.h Lack of concern for rehabilitation of displaced persons}

In the absence of an obligation in law for the state to rehabilitate and resettle affected person, the concerned governments have resorted to most minimum amenities required for shifting the displaced persons after evicting them from the land acquired. Even the limited ad-hoc assurances given to the displaced about rehabilitation to neutralize their opposition to the project have been diluted or reversed in the course of implementation. Government feels that payment of compensation, a provision of a small house and a minimum of infrastructure at the resettlement site is sufficient to discharge its obligation (Sharan, 2010). This has left behind a trail of devastation. The affected persons are left to face an uncertain and bleak future. This deficiency is responsible for increasing hostility of the affected persons to acquisition proposals. A legally 
enforceable commitment to provide comprehensive rehabilitation and resettlement to all the displaced persons who should include, besides financial assistance for subsistence during the transition period, alternative land, employment, residential house, skill development, infrastructure facilities and social amenities has been sought to prevent this catastrophic consequence (Levien, 2011).

\section{Policy:}

4.i Displacement as Sociological Issue and Rehabilitation as Administrative

Both displacement and rehabilitation are social processes taking place at two different and interrelated levels. The nature of the forces underlying these processes is different with respect to the social, geographical, cultural and temporal dimensions of the space where they take shape. The former is a geo-social process which involves involuntary dislocation of the population from their traditional habitat. As a sociological issue, displacement needs to be constructed as a category to include all occurrences of involuntary population movements from original habitats. While constructing the category 'displaced', the reasons for de-territorialization can be identified in the form of a prefix, for example, development-induced displacement, war-induced displacement, revolution-induced displacement, ethnic-violence-induced displacement, and terrorism-induced displacement to name a few (Bhushan, 2008).

We may bring in a distinction between internally displaced and internationally displaced people. The types of displaced mentioned earlier within the national border do not encounter the problems of citizenship and national identity. On the other hand, refugees are internationally displaced who encounter the problem of alienate. Due to various historical reasons India has accepted refugees from the nation-states in the neighbourhood and their number is increasing. Strictly speaking, sociology of displacement should consider issues pertaining to their life too within its scope (Jewitt, 2008).

The displaced are the victims and are therefore vulnerable. They require the support of the state machinery to restart their livelihood in alien environments. The rehabilitation policies enacted by the respective governments are administrative mechanisms to facilitate the displaced to start a decent living in a new environment. The displaced have to build new societies and new cultural atmospheres in new locations. The R\&R policy provides guidelines and support in this process. Though R\&R policy is now synonymous with rehabilitation of the development-induced displaced, ideally it should look into the administrative aspects of the internationally displaced also. However, there is a separate sub-discipline by name Refugee Studies and the Ministries of External Affairs and Home implement the policies relating to their lives. I am of the opinion that to manage the administrative aspects of all the internally displaced peoples we should work towards evolving one inclusive R\&R policy.

\section{Conclusion}

The impact of coal mining on the local public of eastern coal mining region (ECL) of West Burdwan district exemplifies accumulations by dispossession occurring as a result of the new mining policy made by the government in the age of globalization. The indispensable characteristic of growth by dispossession is the replacement of long standing conventional forms of production by new market-based forms of productions and consumptions. In the Sonepur Bazari, Ukhra mining area, accumulations by dispossession is enacted through the process of displacement and force integration of the tribal as well as farmer population using indirect force and conversion of different forms of property rights by the weaknesses of existing laws and also by the $\mathrm{R}$ and $\mathrm{R}$ policies. It also creates a propensity towards polarisation. The adivasi (Tribe) communities of ECL of West Bengal have emerged in their current state of dispossession through stages. The present stage of physical dispossessions can be understood as the final stage with a fundamental changes of traditional ways of subsistence level cultivation to non-agricultural informal sector. This is one of the main characteristics of industrial development (Singh, 2010).

Therefore, the Sonepur Bazari, Ukhra projects of ECL exemplifies two crucial characteristics of accumulation by dispossession. It also describes how the capitalists' affiliation is contingent upon development strategies of Govt and transferring the productive resources in the hands of the few while dispossessing the public from their rights. 


\section{References}

Asian Centre for Human Rights, 2007 - Asian Centre for Human Rights (2007). India's Failed National Rehabilitation and Resettlement Policy, 2007. [Electronic resource]. URL: http://www. achrweb.org/Review/2007/198-07/html.

Bhushan, Monali, 2008 - Bhushan, Chandra, Monali Zeya Hazra (2008). Mining in the Sates: Jharkhand and West Ben-gal. Rich Lands, Poor People: Is 'Sustainable' Mining Possible? State of India's Environment: Sixth Citizens' Report (New Delhi: Centre for Science and Environment).

Corbridge, 2004 - Corbridge, Stuart (2004). Competing Inequalities: The Scheduled Tribes and the Reservation Sys-tem in India's Jharkhand. In S Corbridge, S Jewitt and S Kumar (ed.), Jharkhand: Environment, Development and Ethnicity (New Delhi: Oxford University Press), pp 175-202. Originally published in Journal of Asian Studies, 59(1).

Deininger et al., 2011 - Deininger, K., Derek B. with Jonathan Lindsay, Andrew Norton, Harris Selod and Mercedes Stickler (2011). Rising Global Interests in Farmland: Can It Yield Sustainable and Equitable Benefits, Washington DC, World Bank.

Goswami, 2018 - Goswami, S. (2018). Land acquisition in India: problems and prospects. International Journal of Pedagogy Innovation and New Technologies, Vol.5 (2): 57-67.

Goswami, 2019 - Goswami, S. (2019). Land Rights as Social Rights: A Micro-Level Study. European Researcher, Vol. 10(1): 38-49.

Guha, 2006 - Guha, A. (2006). Dispossession of Peasants by Industrial Projects" in S Jain and M Bala (ed.). The Economics and Politics of Resettlement in India (Delhi: Pearson Longman), pp. 155-73. Press).

Harvey, 2003 - Harvey, David (2003). The New Imperialism (Oxford: Oxford University

Jewitt, 2008 - Jewitt, Sarah (2008). Political Ecology of Jharkhand Conflicts. Asia Pacific Viewpoint, 49(1): 68-82.

Jha-Thakur, Thomas, 2008 - Jha-Thakur., Thomas F. (2008). Are Open-cast Coal Mines Casting a Shadow on the Indian Environment. International Development Planning Review, 30(4): 441-59.

Lahiri-Dutt, 2007 - Lahiri-Dutt, Kuntala (2007). Illegal Coal Mining in Eastern India: Rethinking Legitimacy and Limits of Justice. Economic \& Political Weekly, XLII (49), 8 December.

Lahiri-Dutt, Nesar, 2012 - Lahiri-Dutt, K., Nesar Ahmad (2012). Considering Gender in Social Impact Assess-ments. In Frank Vanclay and Ana Maria Este-ves (ed.), New Directions in Social Impact Assessments: Conceptual and Methodological Advances (Cheltenham: Edward Elgar).

Levien, 2011 - Levien, M. (2011). Rationalising Dispossession. Economic \& Political Weekly, Vol XLVI, No 11, 11 March.

MMSD, 2002 - MMSD (2002). Breaking New Ground: The Report of Mining Mineral and Sustainable Development Project. [Electronic resource]. URL: http://pubs.lied. org/pdfs/8o 84IIED.pdf? (last viewed on 20 January 2011).

Morris, Ajay, 2009 - Morris, Sebastian, Ajay Pandey (2009). Land Markets in India: Distortions and Issues" in India Infrastructure Report, 2009: Land - A Critical Resource for Infrastructure, IDFC (New Delhi: Oxford University Press).

Randeira, 2003 - Randeira, Shalini (2003). Glocalisation of Law: Environmental Justice, World Bank, NGOs and the Cunning State in India. Current Sociology, 51(3-4).

Sharan, 2009 - Sharan, Ramesh (2009). Alienation and Restora-tion of Tribal Land in Jharkhand" in Nandini Sundar (ed.). Legal Grounds: Natural Resources, Identity, and the Law in Jharkhand (New Delhi: Oxford University Press).

Sharma, 2003 - Sharma, M. (2003). Implications of the CBA Act and Coal India R \& R Policy on DPs and PAPs of Raj-mahal Opencast Coal Mine Expansion Project, with focus on Necessity for Gender-Sensitive Rahabilitation Programme Development, Re-port Submitted as a project, Indira Gandhi National Open University, New Delhi.

Singh, Kaliappa, 2003 - Singh, Kanhaiya, Kaliappa Kalirajan (2003). A Decade of Economic Reforms in India: The Mining Sector. Resources Policy, 29: 139-51.

Singh, 2010 - Singh, Ram (2010). Ending Misuse of Land Acqui-sition Act" in the Economic Times, 18 November. [Electronic resource]. URL: http://economictimes.indiatimes. com/opinion/ 
comments--analysis/Ending-misuse-of-land-acquisition-laws/articleshow/6944908.cms (viewed on 8 December 2010).

Stuligross, 2008 - Stuligross, David (2008). Resources, Representa-tion, and Authority in Jharkhand, India. Asia Pacific Viewpoint, 49(1): 83-97.

Szablowski, 2010 - Szablowski, David (2010). Operationalising Free, Prior, and Informed Consent in the Extractive Industry Sector? Examining the Challenges of a Negotiated Model of Justice. Canadian Journal of Development Studies, 30(1-2): 111-30.

Upadhyay, 2009 - Upadhyay, Carol (2009). Law, Custom and Adivasi Identity: Politics of Land Rights in Chhotanagpur" in Nandini Sundar (ed.). Legal Grounds: Natural Resources, Identity, and the Law in Jharkhand (New Delhi: Oxford University Press), pp. 30-55.

Walker, 2011 - Walker, Kathy le Mons (2011). Neoliberalism on the Ground in Rural India: Predatory Growth, Agrarian Crisis, Internal Colonisation, and the Intensification of Class Struggle. Journal of Peasant Studies, 35(4): 557-620.

World Bank, 2007 - World Bank (2007). Jharkhand: Addressing the Challenges of Inclusive Development, Washing-ton DC, World Bank. 